\title{
Response of Drip Fertigation on Growth, Yield and Nutrient Uptake of Soybean in Vertisols
}

\author{
O. P. Rajwade*, S. K. Dwivedi, R. M. Savu, Vidhi Garg and S. K. Gupta \\ Department of Agronomy, Indira Gandhi Krishi Vishwavidyalaya, Raipur-492012, C.G., India \\ *Corresponding author
}

\section{Keywords}

Omega 6 and Omega 3 fatty acid, $4.5 \%$ minerals, $3.7 \%$ fibre, $8.1 \%$ water

\section{Article Info}

Accepted: 26 November 2020 Available Online: 10 December 2020
The field experiment was carried out at Research cum Instructional Farm, Indira Gandhi Krishi Vishwavidyalaya Raipur (C.G.) during Kharif season of 2017-18 to evaluate the Response of drip fertigation on growth, yield and nutrient uptake of soybean in vertisols. There were eight treatment $\mathrm{T}_{1-}-75 \% \mathrm{RDF}$ through fertigation, $\mathrm{T}_{2^{-}}$ $100 \%$ RDF through fertigation, $\mathrm{T}_{3}-125 \%$ RDF through fertigation, $\mathrm{T}_{4}-75 \%$ RDF $(25$ $\%$ Basal $+75 \%$ through fertigation), $\mathrm{T}_{5}-100 \%$ RDF $(25 \%$ Basal+ $75 \%$ through fertigation), $\mathrm{T}_{6}-125 \% \operatorname{RDF}\left(25 \%\right.$ Basal $+75 \%$ through fertigation), $\mathrm{T}_{7}-100 \% \mathrm{RDF}$ through conventional application with drip irrigation, $\mathrm{T}_{8^{-}}$No fertilization with conventional irrigation. The results of experiment indicated that maximum growth were observed with application of $125 \% \mathrm{RDF}$ through fertigation $\left(\mathrm{T}_{3}\right)$, however application of $100 \%$ RDF through fertigation $\left(\mathrm{T}_{2}\right)$ produced significantly maximum seed yield $\left(26.89 \mathrm{q} \mathrm{ha}^{-1}\right)$, while maximum stover yield $\left(32.77 \mathrm{q} \mathrm{ha}^{-1}\right)$ produced with the application of $125 \%$ RDF through fertigation $\left(\mathrm{T}_{3}\right)$ In terms of $\mathrm{N}, \mathrm{P}$ and $\mathrm{K}$ uptake $(\mathrm{kg}$ $\left.\mathrm{ha}^{-1}\right)$ in seed $\left(132.85,17.59\right.$ and $\left.126.44 \mathrm{~kg} \mathrm{ha}^{-1}\right)$ and stover $(105.33,8.66$ and $96.80 \mathrm{~kg}$ $\mathrm{ha}^{-1}$ ) by soybean crop was highest with the application of $100 \%$ RDF through fertigation $\left(\mathrm{T}_{2}\right) . \mathrm{N}, \mathrm{P}$ and $\mathrm{K}$ content \%in seed $(5.39,0.54$ and $4.77 \%)$ and stover (3.50, 0.27 and $3.14 \%$ ) of soybean found significantly higher with the application of $125 \%$ RDF through fertigation $\left(\mathrm{T}_{3}\right)$.The minimum, seed yield $\left(9.77 \mathrm{q} \mathrm{ha}^{-1}\right)$ and stover yield $\left(18.06 \mathrm{q} \mathrm{ha}^{-1}\right)$, nutrient content and uptake were observed under no fertigation with conventional irrigation $\left(\mathrm{T}_{8}\right)$.

\section{Introduction}

Soybean [Glycine max (L.) Merrill] known as a wonder crop of $20^{\text {th }}$ century because it contains about $20.5 \%$ carbohydrates, $20 \%$ oil with poly unsaturated fatty acids specially Omega 6 and Omega 3 fatty acid, 4.5\% minerals, $3.7 \%$ fibre, $8.1 \%$ water and $43.2 \%$ protein, its protein contains all the essential amino acids such as Lysine, Leucine, Lecithin, therefore from nutritional point of view it is known as miracle crop(Chauhan et al., 1988). Soybean builds up the soil fertility by fixing atmospheric nitrogen (45 to $60 \mathrm{~kg} \mathrm{ha}^{-1}$ ) through the root nodules, and adds about 0.5 to 1.5 tonnes $\mathrm{ha}^{-1}$ organic matter in soil 
through leaf fall (Kanase et al., 2006). Among the soybean growing country the United State of America (117.20 M tonnes) is the highest producer of soybean in the world followed by Brazil (96.29 M tonnes), Argentina (58.79 M tones. India is the fourth highest soybean producing country in the world, during 2000, soybean occupies an area of 6.41 million hectares which is now increased to 11.60 million hectares in 2015-16, while the production was 5.27 million tonnes and now it has been recorded to 13.79 million tonnes and the mean national productivity of the crop has increased from $822 \mathrm{~kg} \mathrm{ha}^{-1}$ to $1217 \mathrm{~kg} \mathrm{ha}^{-1}$. The major soybean growing states are Madhya Pradesh (7.20 M ha), Maharashtra (4.55 M ha), Rajasthan (1.17 M ha), Andhra Pradesh, Telangana (0.24 M ha) and Karnataka (0.29 M ha). The crop is fast spreading in southern states such as Andhra Pradesh and Karnataka. Production of soybean in India is dominated by Maharashtra and Madhya Pradesh which contribute $89 \%$ of the total production. Rajasthan, Andhra Pradesh, Karnataka, Chhattisgarh and Gujarat contribute the remaining $11 \%$ production (Annonymus, 2019).

In near future, several developing countries would face major challenge in achieving sustainable food security. Enhancing sustainable food production would require proper and judicious use of available land, water and fertilizer resources. This requires agricultural intensification with the emerging concept of fertigation, scientific usage of micro-irrigation with water-soluble fertilizers and prevention of soil pollution and restoration of soil health. Among the agronomic practices, nutrient and water management play a vital role in determining the yield and quality of the produce. Under these circumstances, cultural methods are to be modified and standardized according to the need of existing market windows and immediate attempts have to be made for maximizing the productivity of crops. This can be achieved through application of adequate quantity of the available water and fertilizers economically. Drip fertigation is a recent innovative and hi-tech method receiving wider acceptance and adaptation, by which fertilizers are applied along with irrigation water through drip system to get higher fertilizer use efficiency besides enhancing the crop yields. Therefore, concerted efforts are now needed to harness the available quantities of water with fertilizer and put them to efficient use to achieve higher productivity per drop of available water and per unit of fertilizer application.

\section{Materials and Methods}

Field experiment was carried out during kharif season (June to October) of 2017 at Instructional cum Research Farm, IGKV, Raipur (C.G.). The climate of the location is sub-humid with hot summer and cold winter. The mean annual precipitation of the region is $1326 \mathrm{~mm}$ (based on 80 years mean), about $85 \%$ of rainfall is received during rainy season that is middle of June to September with occasional showers in winter and summer months. The weekly maximum temperature raises upto $46^{\circ} \mathrm{C}$ during summer and minimum temperature drop down as low as $6^{\circ} \mathrm{C}$ during winter season. The soil of experimental field was clayey in texture (Vertisols) with low N, high $\mathrm{P}$ and $\mathrm{K}$ content. Soybean variety JS 9752 was sown on $28^{\text {th }}$, June 2017 at a spacing of $30 \mathrm{~cm} \mathrm{x} 10 \mathrm{~cm}$ with seed rate of $65 \mathrm{~kg} \mathrm{ha}^{-1}$.

Experiment was laid out in randomized block design with eight treatments in three replications. The treatment comprised $\mathrm{T}_{1-}-75 \%$ RDF through fertigation, $\mathrm{T}_{2^{-}} 100 \% \mathrm{RDF}$ through fertigation, $\mathrm{T}_{3}-125 \% \mathrm{RDF}$ through fertigation, $\mathrm{T}_{4}-75 \% \mathrm{RDF}(25 \% \mathrm{Basal}+75 \%$ through fertigation), $\mathrm{T}_{5}-100 \% \mathrm{RDF}(25 \%$ Basal $+75 \%$ through fertigation), $\mathrm{T}_{6}-125 \%$ RDF (25\% Basal + $75 \%$ through fertigation), 
$\mathrm{T}_{7}-100 \%$ RDF through conventional application with drip irrigation, $\mathrm{T}_{8}$-No fertilization with conventional irrigation. The recommended dose of $\mathrm{N}, \mathrm{P}_{2} \mathrm{O}_{5}$ and $\mathrm{K}_{2} \mathrm{O}$ i.e. 20 : 60: $30 \mathrm{Kg} \mathrm{ha}^{-1}$. Fertilizer was applied as basal dose in the form of urea, single super phosphate and murate of potash. However nutrient from drip fertigation was applied in the form of urea, phosphoric acid and sulphate of potash as source of nitrogen, phosphorus and potassium. Fertilizers were applied with drip as per the treatment requirements Observations were recorded on five random competitive plants at various crop growth stages and at harvest. The seed and stover yield were recorded from net plot area of each treatment and data was converted into $\mathrm{kg}$ per hectare.

Nitrogen was estimated by modified microkjeldahl method, phosphorus was estimated by calorimetric method using a Technicon autoanalyzer and potassium by flame photometry (Jackson, 1967). The uptake of N, P and $\mathrm{K}$ in $\mathrm{kg} \mathrm{ha}{ }^{-1}$ in seed and stover at harvest was calculated by multiplying the nutritional content with the respective dry matter production. The available soil $\mathrm{P}$ was estimated by the method of Olsen et al., (1954). The available $\mathrm{K}$ was estimated by flame photometer (Jackson, 1967).

\section{Results and Discussion}

\section{Effect on growth}

The data on plant height $(\mathrm{cm})$, number of leaves plant ${ }^{-1}$, Leaf area plant ${ }^{-1}\left(\mathrm{~cm}^{2}\right)$, number of branches plant ${ }^{-1}$ and Leaf area index (LAI)has been presented in Table 1.Number of leaves plant ${ }^{-1}$ and Leaf area plant ${ }^{-1}\left(\mathrm{~cm}^{2}\right)$ of soybean was observed at 60 and 90 DAS, while number of branches plant ${ }^{-1}$ and leaf area index were observed at 60,90 and at harvest. The data reveals that the number of leaves plant $^{-1}$ andleaf area plant ${ }^{-1}$ increased sharply from up to 60 DAS in comparison to 60 to 90 DAS. Application of $125 \%$ RDF through fertigation $\left(\mathrm{T}_{3}\right)$,recorded maximum growth parameters and fallowed by treatment $100 \%$ RDF through fertigation $\left(\mathrm{T}_{2}\right)$ and $125 \% \mathrm{RDF}$ ( $25 \%$ Basal $+75 \%$ through fertigation) $\left(\mathrm{T}_{6}\right)$ in general. However, at harvest, there is no further increase in the number of branches plant $^{-1}$ and results are found similar with 90 DAS. Khutale et al.,(2005) found similar result and reveals that the application of $125 \%$ of RDF + FYM @ 5 t ha ${ }^{-1}$ produced significantly higher number of branches plant ${ }^{-}$ 1 (12.60) due to highest physiological efficiency and photosynthetic rate. However, the minimum growth was observed under treatment of no fertilization with conventional irrigation $\left(\mathrm{T}_{8}\right)$.

Higher number of leaves is associated with the higher leaf area and LAI. Higher leaf area might have enhanced the photosynthesis and responsible for higher dry matter accumulation of plant.

\section{Effect on yield (q ha $\left.{ }^{-1}\right)$}

The maximum seed yield (26.89 $\left.\mathrm{q} \mathrm{ha}^{-1}\right)$ was recorded with the application of $100 \% \mathrm{RDF}$ through fertigation $\left(\mathrm{T}_{2}\right)$, which was significantly higher than rest of the other treatments; however, it was statistically at par with the applicationof $125 \%$ RDF through fertigation $\left(\mathrm{T}_{3}\right)$.The lowest seed yield $(9.77 \mathrm{q}$ $\mathrm{ha}^{-1}$ ) was recorded under no fertilization with conventional irrigation $\left(\mathrm{T}_{8}\right)$. The sufficient supply of major nutrient is the key factor for increasing yield of soybean. Significantly higher stover yield (32.77 q ha $\left.{ }^{-1}\right)$ was obtained with the application of $125 \%$ RDF through fertigation $\left(T_{3}\right)$ as compared to other, however it was at par with the application of $100 \%$ RDF through fertigation $\left(T_{2}\right)$, while the significantly lowest stover yield (18.06 q ha $\left.{ }^{1}\right)$ was obtained under the treatment with no fertilization with conventional irrigation $\left(\mathrm{T}_{8}\right)$. 
Table.1 Number of branches plant ${ }^{-1}$, Leaf area plant ${ }^{-1}\left(\mathrm{~cm}^{-2}\right)$, Branches plant ${ }^{-1}$ (No.), Leaf area index plant ${ }^{-1}$, Seed yield $\left(\mathrm{q}\right.$ ha $\left.{ }^{-1}\right)$ and Stover yield $\left(\mathrm{q} \mathrm{ha}^{-1}\right)$ of soybean at different intervals as influenced by fertigation

\begin{tabular}{|c|c|c|c|c|c|c|c|c|c|c|c|c|c|c|}
\hline \multirow{2}{*}{\multicolumn{2}{|c|}{ Treatment }} & \multirow{2}{*}{$\begin{array}{l}\text { Plant } \\
\text { height } \\
(\mathrm{cm}) 90 \\
\text { DAS }\end{array}$} & \multicolumn{2}{|c|}{$\begin{array}{l}\text { Leaves plant }{ }^{-1} \\
\text { (No.) }\end{array}$} & \multicolumn{2}{|c|}{$\begin{array}{l}\text { Leaf area plant } \\
\left(\mathrm{cm}^{-1}\right)\end{array}$} & \multicolumn{3}{|c|}{$\begin{array}{l}\text { Leaf area index } \\
\text { plant }^{-1}\end{array}$} & \multicolumn{3}{|c|}{$\begin{array}{c}\text { Branches plant } \\
\text { (No.) }\end{array}$} & \multirow{2}{*}{$\begin{array}{l}\text { Seed } \\
\text { yield } \\
\left(\mathbf{q} \text { ha }^{-}\right. \\
\left.\mathbf{1}^{\prime}\right)\end{array}$} & \multirow{2}{*}{$\begin{array}{c}\text { Stover } \\
\text { yield } \\
\left(\mathbf{q} \text { ha }^{-1}\right)\end{array}$} \\
\hline & & & $\begin{array}{c}\text { 60 } \\
\text { DAS }\end{array}$ & $\begin{array}{c}90 \\
\text { DAS }\end{array}$ & $\begin{array}{c}\text { 60 } \\
\text { DAS }\end{array}$ & $\begin{array}{c}90 \\
\text { DAS }\end{array}$ & $\begin{array}{c}\text { 30 } \\
\text { DA } \\
\text { S }\end{array}$ & $\begin{array}{c}\text { 60 } \\
\text { DA } \\
\text { S }\end{array}$ & $\begin{array}{c}90 \\
\text { DAS }\end{array}$ & $\begin{array}{c}\text { 60 } \\
\text { DAS }\end{array}$ & $\begin{array}{c}90 \\
\text { DAS }\end{array}$ & $\begin{array}{c}\text { At } \\
\text { harvest }\end{array}$ & & \\
\hline $\mathbf{T}_{1}$ & $\begin{array}{l}\text { 75\% RDF through } \\
\text { fertigation }\end{array}$ & 116.91 & 19.13 & 27.44 & 1383.52 & 1458.67 & 2.85 & 2.85 & 2.85 & 10.11 & 10.44 & 10.44 & 21.75 & 26.49 \\
\hline $\mathbf{T}_{2}$ & $\begin{array}{l}100 \% \text { RDF through } \\
\text { fertigation }\end{array}$ & 123.49 & 22.40 & 29.00 & 1681.38 & 1746.65 & 3.00 & 3.00 & 3.00 & 10.66 & 11.00 & 11.00 & 26.89 & 29.05 \\
\hline $\mathbf{T}_{3}$ & $\begin{array}{l}125 \% \text { RDF through } \\
\text { fertigation }\end{array}$ & 129.97 & 23.33 & 32.66 & 1693.01 & 1835.85 & 3.05 & 3.05 & 3.05 & 11.66 & 12.55 & 12.55 & 24.63 & 32.77 \\
\hline $\mathbf{T}_{4}$ & $\begin{array}{c}75 \% \text { RDF ( } 25 \% \text { Basal } \\
+75 \% \text { through } \\
\text { fertigation })\end{array}$ & 113.44 & 18.66 & 25.77 & 1312.78 & 1465.76 & 2.36 & 2.36 & 2.36 & 10.00 & 10.33 & 10.33 & 21.03 & 26.09 \\
\hline $\mathbf{T}_{5}$ & $\begin{array}{c}100 \% \text { RDF }(25 \% \\
\text { Basal }+75 \% \text { through } \\
\text { fertigation) }\end{array}$ & 120.15 & 19.79 & 27.77 & 1432.70 & 1500.00 & 2.91 & 2.91 & 2.91 & 10.22 & 10.55 & 10.55 & 22.40 & 27.23 \\
\hline$T_{6}$ & $\begin{array}{c}125 \% \text { RDF ( } 25 \% \\
\text { Basal }+75 \% \text { through } \\
\text { fertigation) }\end{array}$ & 127.06 & 20.11 & 28.33 & 1555.63 & 1661.38 & 3.31 & 3.31 & 3.31 & 10.44 & 10.78 & 10.78 & 23.05 & 28.46 \\
\hline $\mathbf{T}_{7}$ & $\begin{array}{l}100 \% \text { RDF through } \\
\text { conventional } \\
\text { application with drip } \\
\text { irrigation }\end{array}$ & 111.35 & 17.89 & 24.33 & 1227.43 & 1296.39 & 2.19 & 2.19 & 2.19 & 9.33 & 9.66 & 9.66 & 17.14 & 25.82 \\
\hline \multirow[t]{3}{*}{$\mathbf{T}_{8}$} & $\begin{array}{l}\text { No fertilization with } \\
\text { conventional irrigation }\end{array}$ & 98.73 & 14.89 & 20.89 & 1110.08 & 1113.09 & 1.94 & 1.94 & 1.94 & 7.29 & 7.44 & 7.44 & 9.77 & 18.06 \\
\hline & SEm \pm & 2.42 & 1.13 & 1.44 & 84.53 & 89.48 & 0.15 & 0.15 & 0.15 & 0.49 & 0.54 & 0.54 & 1.20 & 1.39 \\
\hline & $\mathrm{CD}(\mathrm{P}=0.05)$ & 7.36 & 3.44 & 4.38 & 256.38 & 271.42 & 0.48 & 0.48 & 0.48 & 1.49 & 1.64 & 1.64 & 3.64 & 4.23 \\
\hline
\end{tabular}


Table.2 Nitrogen, phosphorus and potassium content (\%) of soybean as influenced by fertigation

\begin{tabular}{|c|c|c|c|c|c|c|c|}
\hline & \multirow[t]{2}{*}{ Treatment } & \multicolumn{2}{|c|}{$\mathbf{N}$ content $(\%)$} & \multicolumn{2}{|c|}{$P$ content $(\%)$} & \multicolumn{2}{|c|}{ K content $(\%)$} \\
\hline & & Seed & Stover & Seed & Stover & Seed & Stover \\
\hline $\mathbf{T}_{\mathbf{1}}$ & $75 \%$ RDF through fertigation & 4.66 & 2.61 & 0.44 & 0.22 & 4.31 & 2.74 \\
\hline $\mathbf{T}_{2}$ & $100 \%$ RDF through fertigation & 4.85 & 3.21 & 0.52 & 0.26 & 4.71 & 2.96 \\
\hline $\mathbf{T}_{3}$ & $125 \%$ RDF through fertigation & 5.39 & 3.50 & 0.54 & 0.27 & 4.77 & 3.14 \\
\hline $\mathbf{T}_{4}$ & $\begin{array}{l}75 \% \text { RDF (25\% Basal + } 75 \% \\
\text { through fertigation) }\end{array}$ & 4.40 & 2.61 & 0.42 & 0.20 & 3.98 & 2.57 \\
\hline $\mathbf{T}_{5}$ & $\begin{array}{c}100 \% \text { RDF ( } 25 \% \text { Basal }+75 \% \\
\text { through fertigation) }\end{array}$ & 4.74 & 2.92 & 0.46 & 0.23 & 4.36 & 2.90 \\
\hline $\mathbf{T}_{6}$ & $\begin{array}{l}125 \% \text { RDF ( } 25 \% \text { Basal + } 75 \% \\
\text { through fertigation) }\end{array}$ & 5.06 & 3.38 & 0.48 & 0.25 & 4.65 & 2.92 \\
\hline $\mathbf{T}_{7}$ & $\begin{array}{l}100 \% \text { RDF through conventional } \\
\text { application with drip irrigation }\end{array}$ & 4.29 & 2.39 & 0.37 & 0.18 & 3.53 & 2.34 \\
\hline $\mathbf{T}_{8}$ & $\begin{array}{l}\text { No fertilization with conventional } \\
\text { irrigation }\end{array}$ & 3.96 & 2.29 & 0.31 & 0.12 & 3.34 & 2.05 \\
\hline & SEm \pm & 0.24 & 0.22 & 0.03 & 0.01 & 0.19 & 0.13 \\
\hline & $\mathrm{CD}(\mathrm{P}=0.05)$ & 0.71 & 0.66 & 0.08 & 0.04 & 0.59 & 0.39 \\
\hline
\end{tabular}


Table.3 Nutrient uptake $\left(\mathrm{kg} \mathrm{ha}^{-1}\right)$ in soybean as influenced by fertigation

\begin{tabular}{|c|c|c|c|c|c|c|c|c|c|c|}
\hline & \multirow[t]{2}{*}{ Treatment } & \multicolumn{3}{|c|}{ N uptake $\left(\mathrm{kg} \mathrm{ha}^{-1}\right)$} & \multicolumn{3}{|c|}{ P uptake $\left(\mathrm{kg} \mathrm{ha}^{-1}\right)$} & \multicolumn{3}{|c|}{ K uptake $\left(\mathrm{kg} \mathrm{ha}^{-1}\right)$} \\
\hline & & Seed & Stover & Total & Seed & Stover & Total & Seed & Stover & Total \\
\hline $\mathbf{T}_{1}$ & $75 \%$ RDF through fertigation & 101.58 & 69.76 & 171.34 & 11.63 & 5.73 & 17.37 & 93.68 & 72.69 & 166.37 \\
\hline $\mathbf{T}_{2}$ & $100 \%$ RDF through fertigation & 132.85 & 105.33 & 235.72 & 17.59 & 8.66 & 26.25 & 126.44 & 96.80 & 223.24 \\
\hline $\mathbf{T}_{3}$ & $125 \%$ RDF through fertigation & 130.39 & 102.24 & 235.09 & 15.10 & 7.72 & 22.82 & 117.54 & 91.14 & 208.68 \\
\hline $\mathbf{T}_{4}$ & $\begin{array}{c}75 \% \text { RDF (25\% Basal }+75 \% \\
\text { through fertigation) }\end{array}$ & 92.32 & 68.61 & 160.93 & 10.98 & 5.16 & 16.14 & 83.47 & 67.26 & 150.73 \\
\hline $\mathbf{T}_{5}$ & $\begin{array}{c}100 \% \text { RDF ( } 25 \% \text { Basal }+75 \% \\
\text { through fertigation) }\end{array}$ & 106.66 & 80.10 & 186.76 & 12.36 & 6.16 & 18.52 & 97.72 & 78.85 & 176.57 \\
\hline $\mathbf{T}_{6}$ & $\begin{array}{l}125 \% \text { RDF ( } 25 \% \text { Basal }+75 \% \\
\text { through fertigation) }\end{array}$ & 116.26 & 96.88 & 213.14 & 13.59 & 7.23 & 20.82 & 107.12 & 83.37 & 190.49 \\
\hline $\mathbf{T}_{7}$ & $\begin{array}{l}100 \% \text { RDF through conventional } \\
\text { application with drip irrigation }\end{array}$ & 73.10 & 61.83 & 134.93 & 9.63 & 4.55 & 14.18 & 60.36 & 60.43 & 120.79 \\
\hline $\mathbf{T}_{8}$ & $\begin{array}{l}\text { No fertilization with conventional } \\
\text { irrigation }\end{array}$ & 32.07 & 41.12 & 73.20 & 5.56 & 2.14 & 7.70 & 30.34 & 37.32 & 67.67 \\
\hline & SEm \pm & 6.58 & 7.95 & 2.05 & 0.66 & 0.49 & 0.07 & 4.81 & 5.55 & 3.00 \\
\hline & $\mathrm{CD}(\mathrm{P}=0.05)$ & 19.96 & 24.10 & 6.23 & 2.00 & 1.47 & 0.22 & 14.60 & 16.84 & 9.10 \\
\hline
\end{tabular}


Effect of Nitrogen, phosphorus and potassium content $(\%)$ in soybean

The nitrogen, phosphorus and potassium content in seed and stover of soybean crop were influenced significantly due to drip fertigation. Nitrogen content in seed $(5.39 \%)$ and stover $(3.50 \%)$ of soybean were found significantly higher with the application of $125 \%$ RDF through fertigation $\left(\mathrm{T}_{3}\right)$, which was at par with the application of $125 \% \mathrm{RDF}$ $(25 \%$ Basal $+75 \%$ through fertigation) $\left(\mathrm{T}_{6}\right), 100 \%$ RDF through fertigation $\left(\mathrm{T}_{2}\right)$ and $100 \%$ RDF (25\% Basal + $75 \%$ through fertigation) $\left(T_{5}\right)$. Significantly maximum $P$ content in seed $(0.54 \%)$ and stover $(0.27 \%)$ of soybean were found with the application of $125 \%$ RDF through fertigation $\left(\mathrm{T}_{3}\right)$, however it was found similar with $100 \% \mathrm{RDF}$ through fertigation $\left(\mathrm{T}_{2}\right), 125 \%$ RDF $(25 \%$ Basal +75 $\%$ through fertigation) $\left(\mathrm{T}_{6}\right)$ for seed and stover and $100 \%$ RDF $(25 \%$ Basal $+75 \%$ through fertigation) $\left(\mathrm{T}_{5}\right)$ in case of seed only. Potassium content in seed (4.77\%)and stover (3.14\%) of soybean was found significantly maximum with the application of $125 \% \mathrm{RDF}$ through fertigation $\left(T_{3}\right)$, however it was found similar with $100 \%$ RDF through fertigation $\left(\mathrm{T}_{2}\right), 125 \%$ RDF $(25 \%$ Basal $+75 \%$ through fertigation) $\left(\mathrm{T}_{6}\right)$ and $100 \% \mathrm{RDF}(25 \%$ Basal + $75 \%$ through fertigation) $\left(\mathrm{T}_{5}\right)$. The significantly minimum $\mathrm{N}, \mathrm{P}$ and $\mathrm{K}$ content in seed $(3.96 \% \mathrm{~N}),(0.31 \% \mathrm{P})$ and $(3.34 \% \mathrm{~K})$ and stover $(2.29 \% \mathrm{~N}),(0.12 \% \mathrm{P})$ and $(2.05 \%$ $\mathrm{K})$ were recorded under no fertilization with conventional irrigation $\left(\mathrm{T}_{8}\right)$.

Effect on Nitrogen, phosphorus and potassium uptake by soybean

Data on the nitrogen uptake by seed and stover indicated that maximum nitrogen uptake (132.85 $\left.\mathrm{kgha}^{-1}\right)$ was recorded with the application of $100 \%$ RDF through fertigation $\left(\mathrm{T}_{2}\right)$, which was found at par with the application of $125 \%$ RDF through fertigation
$\left(\mathrm{T}_{3}\right)$ and $125 \%$ RDF (25\% Basal $+75 \%$ through fertigation) $\left(\mathrm{T}_{6}\right)$. Similarly, nitrogen uptake by stover $\left(105.33 \mathrm{~kg} \mathrm{ha}^{-1}\right)$ was recorded significantly maximum with the application of $100 \%$ RDF through fertigation $\left(T_{2}\right)$, which was found at par with the application of $125 \%$ RDF through fertigation $\left(\mathrm{T}_{3}\right), 125 \%$ RDF (25\% Basal +75 $\%$ through fertigation) $\left(\mathrm{T}_{6}\right)$ and $100 \% \mathrm{RDF}$ ( $25 \%$ Basal $+75 \%$ through fertigation) $\left(\mathrm{T}_{5}\right)$.

Phosphorus uptake by seed(17.59 $\left.\mathrm{kg} \mathrm{ha}^{-1}\right)$ was significantly higher with the application of $100 \%$ RDF through fertigation $\left(\mathrm{T}_{2}\right)$, However, maximum $\mathrm{P}$ uptake by stover $\left(8.66 \mathrm{~kg} \mathrm{ha}^{-}\right.$ $\left.{ }^{1}\right)$ was recorded with the application of $100 \%$ RDF through fertigation $\left(T_{2}\right)$, but it was found at par with the application $125 \% \mathrm{RDF}$ through fertigation $\left(\mathrm{T}_{3}\right)$ and $125 \%$ RDF $(25 \%$ Basal + $75 \%$ through fertigation) $\left(\mathrm{T}_{6}\right)$,

Maximum K uptake by seed (126.44 $\mathrm{kg} \mathrm{ha}^{-1}$ ) and stover $\left(96.80 \mathrm{~kg} \mathrm{ha}^{-1)}\right.$ of soybean was recorded with the application of $100 \% \mathrm{RDF}$ through fertigation $\left(T_{2}\right)$, which was found at par with the application of $125 \%$ RDF through fertigation $\left(T_{3}\right)$.

Total nitrogen, phosphorus and potassium uptake in seed and stover(235.72 $\mathrm{Nkg} \mathrm{ha}^{-1}$ ), $\left(26.25 \mathrm{Pkg} \mathrm{ha}^{-1}\right)$ and $\left(223.24 \mathrm{Kkg} \mathrm{ha}^{-1}\right)$ were maximum with the application of $100 \%$ RDF through fertigation $\left(\mathrm{T}_{2}\right)$, which was found at par with the application of $125 \%$ RDF through fertigation $\left(\mathrm{T}_{3}\right)$,whereas significantly minimum N,P and $\mathrm{K}$ uptake in seed (32.07 $\left.\mathrm{Nkg} \mathrm{ha}^{-1}\right),\left(5.56 \mathrm{Pkg} \mathrm{ha}^{-1}\right.$ ) and $30.34 \mathrm{Kkg} \mathrm{ha}^{-}$ ${ }^{1}$ )and stover (41.12 $\left.\mathrm{Nkg} \mathrm{ha}^{-1}\right),\left(2.14 \mathrm{Pkg} \mathrm{ha}^{-1}\right)$ and $\left(37.32 \mathrm{Kkg} \mathrm{ha}^{-1}\right)$ were recorded under no fertilization with conventional irrigation $\left(\mathrm{T}_{8)}\right.$.

\section{References}

Anonymous. 2019. Selected State/Season wise Area, Production and Productivity of soybean in India (2018-19\&2019- 
20).https://www.indiastat.com/table /agriculture/2/soybean/17199 /454876/data.aspx.

Chauhan, G.S., Verma, N.S. and Basin, G.S. 1988. Effect of extrusion processing on the nutritional quality of protein in rice legume blends. Nahrung,32: 43

Kanase, A.A., Mendhe, S.N., Khawale, V.S., Jarande, N.N.and Mendhe, J.T. 2006. Effect of integrated nutrient managment and weed biomass addition on growth and yield of soybean. Journal of Soil Crops, 16 (1): 236-239

Khutale, N. G., Mendhe, S. N., Dongarkar,
K.P, Gudadhe, N. N. and Gavande, V. H. 2005. Effect of nutrient management treatments on growth and yield of soybean, Journal ofSoil and Crops 15(2): 411-4.

Jackson, M L., 1967. Soil and plant Analysis, Bombay, New Delhi, Asia Publishing House. pp. 30-8.

Olsen, S.R., Cole, C.V., Watanable, F.S. and Dean, L.A. 1954. Estimation of available phosphorus in soils by extraction with sodium carbonate. United State Department of Agriculture Circular No. 939: 1-9.

\section{How to cite this article:}

Rajwade, O. P., S. K. Dwivedi, R. M. Savu, Vidhi Garg and Gupta, S. K. 2020. Response of Drip Fertigation on Growth, Yield and Nutrient Uptake of Soybean in Vertisols. Int.J.Curr.Microbiol.App.Sci. 9(12): 3545-3552. doi: https://doi.org/10.20546/ijcmas.2020.912.421 